addition, the building includes a library, the furniture for which was made in Messrs. Pilkington Brothers own carpentry and cabinet-making shops. The library already contains a nucleus of about 2,000 books, including a number of the earliest records of the firm dating from 1869. A number of striking examples of coloured glasses and fluorescent glass were shown in the laboratories. Both the exhibits and the equipment of the laboratories fully justified Sir William Bragg's remarks as to the national importance of the inauguration of this new research institution.

\title{
Fifth International Congress for Applied Mechanics
}

\begin{abstract}
$\mathrm{T}$ HE Fourth International Congress for Applied Mechanics was held at Cambridge, England, in 1934, and the Fifth very appropriately met at Cambridge, Massachusetts, on September 12-16. The Congress was attended by more than four hundred members as the guests of Harvard University and the Massachusetts Institute of Technology. More delightful hosts could not have been desired by the members who shared in the meetings and in the entertainments arranged by the local committee consisting of H. M. Westergaard, J. P. Den Hartog, J. C. Hunsaker, L. S. Marks and H. Peters.

The Congress was opened by Prof. K. T. Compton, president of the M.I.T., acting as president of the Congress. The work of the Congress was accomplished by means of technical sessions at which communications from members were read, by general lectures, and by a symposium on turbulence. The field of applied mechanies was divided into the following general heads : (I) Structures, elasticity, plasticity, fatigue, strength theory, crystal structure. (II) Hydro and aerodynamics, gas-dynamics, hydraulics, meteorology, water waves, heat transfer. (III) Dynamics of solids, vibration and sound, friction and lubrication, wear and seizure. Simultaneous sessions of the three sections were held. Abstracts of the papers presented were printed in English in the September issue of the Journal of Applied Mechanics, a copy of which was given to each member. Communications were received from the following workers from the British Empire : S. Brodetsky, L. P. Coombes, J. N. Goodier, A. A. Hall, C. E. Inglis, G. J. Klein, L. M. MilneThomson, E. F. Relf, F. G. Richardson, D. M. Smith, A. V. Stephens, J. L. Synge, and G. I. Taylor, who gave a general lecture on turbulence. The meetings were held at the M.I.T. for the first four days, and on the last day at Harvard University.
\end{abstract}

On Monday, September 12, members were able to be present at the dedication at the M.I.T. of the Wright Brothers Wind Tunnel, among the speakers at the opening ceremony being G. Brewer, of the Royal Aeronautical Society. The tunnel is a closed welded cylindrical steel circuit, with a 2,000 h.p. electric-motor and a variable pitch propeller, in which the air can be compressed to four atmospheres giving a Reynolds' number of $6,500,000$, or exhausted to one quarter of an atmosphere, when a velocity of 400 miles per hour is expected to be attained. The working section of this remarkable tunnel is an ellipse, ten feet by seven and a half feet.

Apart from attending lectures and hearing papors read, one of the great advantages of an international Congress is the opportunity of scientific workers from different countries meeting personally and exchanging ideas in a quite informal fashion. This opportunity was amply afforded by the receptions and conversaziones which were organized for each evening and contributed in no small measure to the success of the meetings. The largest social undertaking, apart from the final dinner, was the excursion on Thursday, September 15, to Middlesex School, the route passing through Lexington and Concord, places famous in American history. At the School a picnic supper was served, an address on Galileo's "Discorsi" was given by Dean S. H. Hollister, of Cornell University, and the proceedings were thereafter enlivened by a bonfire and a male chorus of Boston Negroes.

Following the Congress, members were invited to visit the National Bureau of Standards at Washington, D.C., and the aeronautical laboratory at Langley Field, Virginia. Many members availed themselves of this opportunity of seeing important scientific work in progress, and some very pleasant parts of the United States.

\section{New Laboratories of the Metropolitan Water Board}

WW Laboratories of the Metropolitan Water
Board were opened by the Minister of Health,
the Right Hon. Walter Elliot, M.P., on October 17
in the presence of a distinguished company. They
are situated at New River Head, Rosebery Avenue,
adjacent to the Boord's head offices, and replace
laboratories in Nottingham Place, which have been
in use since 1905.
The Metropolis Water Act of 1871 provided for
the appointment of a 'water examiner' by the Board
of Trade, and in early days the water supplied by the London water companies was subjected to daily examination by Sir William Crookes and Profs. James Dewar and Percy Frankland. Under the Metropolitan Water Act, 1902, by which the several existing water companies were consolidated into one undertaking under the newly constituted Metropolitan Water Board, the Board was similarly placed under an obligation to conduct chemical and bacteriological examinations of its water.

The Board in 1905 appointed the late Sir Alexander Houston to be "Director of Water Examinations"; 